\title{
The Protection of Indonesian Batik Products in Economic Globalization
}

\author{
Dewi Sulistianingsih ${ }^{1 \mathrm{a}}$, Pujiono $^{1 \mathrm{~b}}$ \\ ${ }^{1}$ Department of Private and Commercial Law , Faculty of Law, Universitas Negeri Semarang (UNNES), Indonesia \\ ${ }^{\mathrm{a}}$ dewisulistianingsih21@gmail.com, ${ }^{\mathrm{b}}$ Pujionosh@yahoo.co.id
}

\begin{abstract}
Batik is one of Indonesia's cultural heritage whose existence has been recognized by UNESCO since 2009. It has become the identity and characteristic of Indonesia that needs to be preserved and developed. Indonesian people can preserve it by recognizing its products' existence and conducting development efforts by improving the quality of its products. In Indonesia, batik has been passed down from generations by wearing, producing and marketing its products. The article is the result of a study using a socio-legal method. The data collection was conducted through interview and observation techniques. The research subjects are batik business owners in Indonesia. This paper reveals the challenges and obstacles faced by the local batik product business people in Indonesia in the face of economic globalization. There have been legal efforts to provide protection for the Indonesian batik products. The problems are how the protection is applied and how the country and the community perform the protection. The other objective of this paper is to analyze the readiness of the local batik businesspeople in Indonesia in the face of economic globalization especially from the legal perspective. The article exposes the batik business owners' weaknesses and seeks to give sound solutions which is hoped to be applied by the batik business owners in Indonesia in order to survive in the globalization era. The solutions are considered to be able to answer challenges faced by Indonesia's batik products to exist in the globalization era.
\end{abstract}

\section{Keywords—Batik Products; Indonesia; Economic Globalization}

\section{INTRODUCTION}

The people of Indonesia have been familiar with batik products. They are thought to have existed far before Indonesia as a nation was formed. Indonesian batik shows the identity of Indonesia. The batik can be three kinds, i.e. handmade, print, and the combination of handmade and print batiks (Ministry of Trade, 2012: 4). Batik is an ancient method of textile decoration which has been practiced in many places all over Asia since prehistoric times (Haake, 1989: 815). Indonesian people are accustomed to wearing batik in their daily activities and in special moments. It can be understood that why Indonesian people are so well familiar with batik products. Indonesia is rich of cultures and arts, and batik is the misture between the cultures and arts in Indonesia. UNESCO has acknowledged that batik to be Indonesia's cultural heritage since 2 Oktober 2009.

A number of motifs have reached what can be referred to as a classical level and since 2 October 2009, Indonesian batik has been recognized by UNESCO as a Masterpiece of the Oral and Intangible Cultural Heritage (Budi, 2016: 54). The acknowledgement opens oprtunities for Indonesia to develop and preserve it as its culture. The preservation efforts focus on emphasizing that batik is the national identity and strong characteristic. The batik development efforts are carried out through quality enhancement of the batik products.

Essentially, the batik production is by decorating the fabric surface using a wax-resist technique, applying wax as the color rhythm, a pre-modern heritage technique whuch is up to this date able to overcome both advantegous and disadvantegous conditions caused by modernity and becomes a contemporary tradition. The design of batik patterns and its diversity uses illustrate the diverse faces of the Javanese people that are constantly changing over time. The traces of Hinduism, Buddhism and Islam can be found in addition to the ethnic and custom diversities that characterize them. Throughout batik history, migrants, adventurers and colonizers have contributed their influences in Java and one of their main artistic products is batik (Elliott, 2004: 22). This long history of batik deserves to be appreciated and preserved as part of Indonesian culture. The culture of producing, using and marketing batik products is a must for the people of Indonesia as a form of Indonesian pride. Indonesia batik products are timeless. This is the evidence that the preservation efforts are successfully carried out.

In addition to the preservation, the development efforts are also important to carry out. The development of batik products needs to be introduced to the next generation in Indonesian. Moreover, the batik products must also be developed and marketed out of Indonesia as a form of economic development of Indonesian society and a form of appreciation of Indonesian culture.

In the current era of globalization, it is important to see batik products in the international arena. This is to prove the existence of Indonesian batik products as part of trade commodities. Batik is made not only as a presentation of art and culture of Indonesian society but it can also be presented to improve the Indonesian economy. However, it is not easy for Indonesian batik products to become a trading commodity, especially in the current era of globalization. It needs a lot of preparation to be done either by Indonesian government, batik emtrepreneurs, stakeholders, and even Indonesian society in general. 
Batik entrepreneurs play an important role in introducing Indonesian batik products to the international world. They will compete not only internationally but also globally. Internationally, they will only compete and market the products to one or two other countries (e.g. Malaysia, Singapore, Thailand). Globally, they are required to market their batik products to many countries in the world. This becomes a challenge for them because it was possible for companies that have previously done international competition and that have a very strong national market position with the international market and lead their competitors in various countries

The batik entrepreneurs in trading batik products make various efforts to interest their business partners. They need to possess a broad understanding the batik business. They should be able to explain that batik is an original culture of Indonesia that has great aesthetic and historical values. Since generally the making of batik itself is very complicated and takes a long time, the price of batik is relatively expensive (Lusianti, 2012: 14).

The challenge that must be faced by the Indonesian batik entrepreneurs is not only must they internationalize the batik products but they must also survive in the global competition. It is not easy for the products to go out into the global arena, given their strong local characteristics and uniqueness can not be customized significantly (but may be modified by not eliminating their characteristics). Not all countries can understand the art and culture found in batik. The batik entrepreneurs must be able to target the right consumers.

\section{RESEARCH METHOD}

This research is qualitative using a socio-legal approach method. The legal aspect of the research is the analysis of how the law, as a norm, for this time being is still unable to apply its regulations to develop local batik products in the economic globalization era. The social aspect of the research is when the research is used to see clearly the realities existing in the community about the development of local batik products and their competitors in the market share. In this research, the data are obtained through observation, interview, literature research activities.

\section{RESULT AND DISCUSSION}

\section{A. The Preservation and Legacy of Batik}

The batik products have two important perspectives to be studied i.e. batik products in the perspective of preservation and legacy. The other perspective is that they are traded products.

The Indonesian people apply cultural values as filters in acting and behaving in responding to the effects of globalization (Hindaryatiningsih, 2016: 108). Reviewing batik product is similar to reviewing values. The Values of batik products are results of acculturation process among the Javanese, Hindu, and Islamic cultures added to cultural influences of immigrants (Pramono, 2013: 134). Batik is not just a legacy of valuable goods with high selling value, but it is also a cultural symbol, through which Indonesia shows its identity.
In the era of globalization of domestic culture needs to be developed and preserved so that the existing culture in Indonesia can be known domestically and in international. To survive in the exposure of globalization, the person or nation needs an identity (Rosyidah, 2016: 13). Batik products are part of Indonesian identity. Batik is not just a legacy of valuables that have a high economic value, but batik also a symbol of cultural, and its identity of Indonesia (Moersid, 2013: 122). Thats why Indonesia tries hard to make Batik as Indonesian Cutural Heritage (Iskandar, 2017: 1). It also aims at revealing and explaining as well the importance of identity in globalization era. On every piece of batik cloth are a million stories that have elements of art and history that make it worth preserving. The values contained in batik products have a very high philosophical level which is a reflection of the values of Indonesian people.

The concept of batik aesthetics today is no longer just an identification but through emphasizing on the identity of batik, there is an extension of orientation that is no longer only regional or national but has expanded to the global by redifining and repositioning themselves. In one hand, the techniques, media and traditional design are preserved. On the other hand, the innovation, promotion and market expansion are carried out until the arena of cultural production is expanded by continuing the local negotiation practices and global dialogue as sources of creativity (Elliott, 2004: 22). Batik products have been introduced as part of Indonesian culture that is able to appreciate the cultural values of Indonesian people. Mass media are some tools to channel and introduce Indonesian batik products in the national and international arenas. The mass media have the role of introducing Indonesian batik products not only in the national arena but also in the international arena.

Batik is a masterpiece of our cultural heritage which has continued to flourished over the years and has shown signs of becoming even more widespread boosted by the dynamic development in technology, aesthetics, and economy. Batik has developed to be an important industry that contributes considerably to the Indonesian economy through export (Ministry of Trade, 2008:1)

In addition, in order that Indonesian batik products can be accepted by the international market globally, it is necessary to carry out various actions like to introduce batik products to international consumers. Batik products must also be able to provide satisfaction for the international consumers. The steps to introduce Indonesian batik to the national and international arenas have been carried out by Indonesian government, entrepreneurs, and the people of Indonesia. The consumer satisfaction must be accompanied by the product quality by using a good brand usage, raw material selection, production process, packaging, and labeling on the batik products.

Batik products are the work of Indonesian culture and inter-regional trade production as well as one of Indonesia's mainstay export commodities. As one subsector in creative industry, batik development can be seen from value of exports and batik production continues to increase overtime (Krisnawati, 2016: 190). The data from Ministry of Industry of Republic of Indonesia recorded that the export value of batik products until October 2017 reached USD 
51.15 million or increased from the achievement of the $1^{\text {st }}$ semester of 2017 which was USD 39.4 million. The main market destinations were Japan, the United States, and Europe.

The export activity has become one of Indonesia strategies in increasing Batik to expand the market for Indonesian products. The activities of Indonesian Batik export to foreign countries have quite a big influence on foreign exchange (Ningsih, 2015: 2). The value of batik export even reached US\$ 32.28 million in 2008, and US\$ 10.86 million in the first three months of 2009 (Ulum, 2009: 21). Reviewed from the data of Indonesian batik export value to foreign countries from 2010- 2014, there had been a significant increase in the export of batik. As a matter of fact, the export value of Indonesian batik in 2010 was as much as 22 million USD, and then increased to 340 million USD in 2014 , which means there had been an increase by $1445 \%$ in the last five years (Zahidi, 2017: 2). Increasing the number of National Batik exports will certainly help in generating foreign exchange, it will be good on the national trade balance (Hidayat, 2015: 2).

\section{B. The Readiness of Local Batik Entrepreneurs in Indonesia}

The globalization can both bring benefits and create a threat to the Indonesian economy. To protect itself, Indonesia implements a policy that can be profitable, at least for Indonesia. In Indonesia, some regions have implemented a policy to wear batik at certain occasions (such as: school, work environment, official events, etc.). This is done to improve the usage of batik and improve the regional economy through batik products.

The raising of batik industry caused some multiplier effects to economics and socio cultural in Indonesia. In many areas of industry, banking role has always beenthe man behind the scene. Banking role in Indonesia also gives some encouragement and be part of batik industry development. Many national event has been created by some banks to encourage SME in batik industry to market their product internationally (Steelyana, 2012: 116).

Indonesia has a variety of batik products. There are many areas in Indonesia that produce batik. There are Pekalongan, Jogjakarta, Cirebon, Solo, Lasik, Kalimantan, Irianjaya batiks, etc.. The local batik products are a valuable asset for Indonesia.

The Government of Indonesia issued the Presidential Decree no. 33 of 2009 on National Batik Day. The issuance of the decree will imply the wearing of batik by the civil servants, employees of SOEs, and private employees. They are required to wear batik clothes on Friday or other days. School students on certain days are also required to wear batik uniforms. This is a good step and opens a market share for batik producers.

The competitiveness of a nation is determined by the industry's ability to innovate and improve its capabilities (Elliott, 2004: 22). At the international level, Indonesia has not optimized itself to make the Indonesian batik products excel in the world of international business. The tight competition in the business world and a specific market share has not made Indonesia's batik products dominate.
There has not been any policy from the Indonesian government that supports the Indonesia's batik products to able to compete in the international arena until recently. It is not necessarily because of Indonesia's inability, but simply because Indonesian batik products face difficulties to be successful in the global business world. Preparation and a mature strategy and support of all parties are necessary.

In order that the Indonesian batik products able to compete in the era of globalization, it is necessary to apply some concrete actions, namely: (1) preparing batik products with national and international standards; (2) expanding the marketing through the online network and attending local and international exhibitions; (3) protecting the products with the applicable law. These actions must be done consistently and have high continuity. If they are seriously carried out Indonesian batik products can undoubtedly exist globally.

Nowdays, small and medium batik entrepreneurs have ever done cooperative marketing, they are: online marketing, exhibition, customers networking, consignment, direct selling/showroom, door to door and sample of product (Maryam, 2015: 72).

It can not be denied that in the era of globalization local products must be able to compete with other products in the international arena. To market the local products abroad means expanding their marketing geographical segmentation. There certainly will be consequences towards the targeted market. Therefore, entrepreneurs need to review the suitability between the product and the local market, in terms of demographic segmentation, psychography, and consumer behavior. This step is important to ascertain what strategy will be taken to gain market in other countries. Since then it will be able to know what values can be properly delivered to the local market.

Entrepreneurs must be able to create somthing new and different to provide new added value and new strength in competition. If the old product is getting saturated, product innovation must be done immediately. Innovation in new creations will continuously give satisfaction to consumers (Suryana, 2013: 207). Batik as an Indonesian cultural product is durable and not static; over time, it communicates culturally within the development of the society. Batik motifs, for instance, continues to develop to win social acceptance (Saddhono, 2014: 53). The aggressive flow of imported Batik to Indonesia creates a big challenge for local producers to become more competitive. Thus, standardization becomes one of the strategies to improve quality and competitiveness (Alhusain, 2015: 199)

Indonesian batik products must have a competitive advantage. The inter-state trade, originally based on the theory of comparative advantage, has now shifted into a competitive advantage. The technological development allows countries that initially have no comparative advantage, can become a major producer of export products that have a competitive advantage. Therefore, Indonesian batik products need to develop competitive advantage to be exported in global market.

The theory of absolute superiority proposed by Adam Smith is in fact difficult to implement because there is no country that really has an absolute advantage over their 
commodity. In addition, there are some countries that have an absolute advantage over the same commodity like Malaysian, Chinese, Thai, Indian, and South African batik products, etc. Indonesia is not the only country that has batik. This fact can not be denied that Adam Smith's theory can not play a good role for Indonesian batik products in the global arena.

Based on the comparative theory, Indonesian batik products will be unable to compete with the Chinese batik products which have relatively cheap price and wider market share. Indonesian batik products will be able to compete globally if they have competitive advantage. So it is necessary to perform 3 concrete actions that have been mentioned that is to standardize batik products nationally and internationally, expand market share, conduct legal protection.

Indonesia's domestic markets were filled up by imported 'batik' products from other countries. Those imported products, which local batik communities mention as (only) 'textille with batik pattern/motifs,' came from China and Malaysia (Sardjono, 2015). Imported Chinese batik products circulating in Indonesia can be found in many regions in Indonesia. It can be said that Indonesia is 'flooded' by Chinese batik products. Indonesia has never tried to decrease imported Chinese batik products, but made efforts to optimize batik Indonesia to have a competitive power. Local Batik has advantages compared to imported Batik, and batik products have their own markets because of the ability and the consumers choices to buy and use local Batik (Sardjono, 2013: 488-489). Indonesia's batik products globally marketed not only in the form of cloth but also must be in a more varied form such as modified batik for accessories, tablecloths, blankets, shoes, wallets, curtains, bags, etc.

The obstacles of Indonesia's batik products to penetrate the global market are the traditional batik making technology. In fact there is no technology in the manufacture of batik. This is why batik making takes a long time. However, the peculiarities and traditional properties of the batik will be lost if modern technology is used. This is the position of dilemma in manufacturing batik in Indonesia. Indonesian local culture, its possible to be marginalized by the global culture if the Indonesia people dont have a conductive culture in their diverse society. Another obstacle is that the entrepreneurs lack good understanding and insight in international business. There are more entrepreneurs rely on the government policy and support. Obviously this depends on the political will of the government. The entrepreneurs should be able to work independently without having to wait for government efforts. The other obstacle is that the entrepreneurs do not have the cost to support exports, the high standards implemented by the government such as production standards, labels, environmental standards.

Penetrating the overseas market requires a lot of preparation and research. Before Indonesian batik products are successfully marketed in overseas markets, entrepreneurs need to familiarize themselves with the various cultural norms and legal considerations of the local country.
Indonesian batik products must be able to adjust to the needs in some countries

It is also important is to learn the laws of commerce, copyright and protection of local consumers. This is related to the flow of the business activity in the future. Do not let batik products marketed abroad disappoint consumers.

\section{The Protection of Indonesia's Batik Products}

The protection of Indonesia's batik products needs to be done to provide assurance to prevent Indonesian batik products from being claimed by other parties or other countries. In addition, the protection also serves to maximize domestic production, expands employment (especially for MSMEs), as an effort to conserve and inherit the culture, avoiding risks that may arise. The protection can be done in two things: legal protection and non-legal protection.

The legal protection may use intellectual property rights. The legal protection of intellectual property rights is very important in a country, in recognition of the work of the creators produced by the intellectual property of human beings and as a guarantee of legal protection of intellectual property that has been produced. One that can sustain development is intellectual property rights which are derived from the activities of human thinking ability expressed to the general public in various forms. They should have benefits, be useful in supporting human life, and also have an economic value. Since then, the owner of the right deserves to be awarded and safeguarded for his or her success in producing an innovative work of creation.

The concept of Intellectual Property is based on the idea that the intellectual works that man has produced require labor, time and cost. The existence of these sacrifices makes the work that has been produced has economic value because of the benefits that can be enjoyed. Based on the concept, it encourages the need for an award for the work that has been produced in the form of legal protection for Intellectual Property. The purpose of enforcing this legal protection is to encourage and cultivate the spirit of work and create (Mashdurohatun, 2017: 192).

The batik products in Indonesia can be protected by Copyright, Mark, Patent, Industrial Design, or Geographical Indications. Batik art work can be protected by Copyright. This is contained in Article 40 paragraph (1) letter j Act No. 28 of 2014 on Copyright. The CA regulates the expression of traditional culture, but batik is not included in it. It is not included in the protection of traditional cultural expressions, though batik is actually a traditional culture. What can be protected as a traditional cultural expression according to the CA are prose, poetry, music, dance, theater, art, and custom ceremony.

The copyrights of batik can be registered at the Directorate of Copyright and Industrial Design, The Directorate General of Intellectual Property, Ministry of Justice and Human Rights. The registration of Geographical Indication shall be done directly to the Directorate of Trademark and Geographical Indication, Directorate General of Intellectual Property of the Ministry of Justice and Human Rights.

Batik can use paten rights, especialy creations in Batik dyeing and coloring. This is because the process of 
making Batik using natural coloribg materials. Its using technology that has high value and produces a unique and distictive color system which is also the scope of patent protection (Widihastuti, 2013: 151).

The Indonesian government has also issued a brand certification through the Ministry of Industry, which is called Batikmark. It serves as the certification of Indonesian batik products. It is introduced by the Ministry of Industry through the Regulation of the Minister of Industry of Republic of Indonesia No. 74/M-IND/PER/9/2007. It is a combination of collective brand concept and certification. It can be given to batik entrepreneurs who already have a registered brand and their products have been certified by the National Standardization Agency (BSN), which has met the Indonesian National Standardization (SNI).

Non-law protection can be done by continuously innovating batik products, doing batik exhibitions and performances both domestically and abroad, always introducing batik in every opportunity, using Indonesian batik products.

\section{CONCLUSION}

Indonesia is not the only nation that produces batik, but Indonesia is one of the countries that carry out the preservation and inheritance of batik products with a very hard effort. The challenge faced by Indonesia is how batik products are able to compete globally. The uniqueness and traditional properties attached to batik must enable us to fight in the global era. Maintaining the character of batik that has characteristic of Indonesian culture is not easy considering that the world has a culture that is not necessarily the same as that of Indonesian.

In the globalization era, it is necessary that Indonesia's entreprenuers to perform real actions in globalizing their batik products around the world. This is not an impossible thing to do considering that the Indonesia's batik products have a high quality and cultural value. All parties, including the government, the business owners, and the community, need to have power to totally support in globalizing Indonesia's batik products. Even in Indonesia, there are not many entrepeneurs who market their products gobally. The entrepeneurs who have tried to market their products globally are Batik Pekalongan, Batik Solo, and Batik Djogdjakarta, Balines Batik. The batik products are marketed via internet media with a low security level.

The legal protection for Indonesia's batik products in the globalization era is inevitable. The legal protection can be carried out through intellectual property mechanism or other possible legal instruments. The protection will create positive legal consequences for Indonesia. It does not only provide legal certainty but also benefits for the batik product entrepreneurs in Indonesia. If there is a legal certainty assurance, there will be comfort in doing business to support the performance and development of Indonesia's batik products.

\section{ACKNOWLEDGMENT}

Acknowledgments are shared with colleagues who have provided various aids for this writing in the form of inputs, suggestions, and literature readings. May it be something worthy of a worship charity.

\section{REFERENCES}

[1] Haake. (1989). The Role of Symmetry in Javanese Batik Patterns. Computers Math. Applic. Vol. 17, No. 4-6, hh 815826.

[2] Alhusain, Achmad Sani. (2015). Efforts and Obstacles in the Development of Batik Industry in Surakarta towards Standardization. Ekonomi \& Kebijakan Publik Journal, Vol. 6, No. 2, pp 199-213

[3] Budi, Setyo. (2016). The Mandala System in Classical Surakarta Style Javanese Batik Motifs. Asian Journal of Social Science \& Humanities. Vol. 5 (1), February, pp 41-48.

[4] Hindaryatiningsih, Nanik. (2016). Model of Inheritance of Local Culture Values in Tradition of Button Society. Sosiohumaniora, Vol. 18, No. 2, (July), pp 108-115.

[5] Iskandar \& Eny Kustiyah. (2017). Batik as Cultural Identity of Indonesian Nations in the Globalization Era. Gema Journal, XXX/52, pp 2456-2472.

[6] Lusianti, Leni Putri \& Faisyal Rani. (2012). Indonesian Diplomacy Model with UNESCO in Patenting Batik as Indonesian Cultural Heritage in 2009. Transnasional Journal, Vol. 3, No. 2, (February), pp 1-19.

[7] Maryam, Siti. (2015). Gotong Royong Marketing Formulation to Improve Batik in Kampoengbatik Laweyan. Journal of Business \& Economic Policy, Vol. 2, No. 3, pp 6974.

[8] McCabe Elliott, Inger. (2004). Batik, Fabled Cloth of Java. Singapore: Periplus Editions

[9] Ministry of Trade (MoT) Republic of Indonesia. (2012). Efforts to Exploit Batik in International. Jakarta: Warta, pp 120.

[10] Ministry of Trade (MoT0 Republic of Indonesia. (2008). Indonesian Batik: a Cultural Beauty. Jakarta: Treda, pp 1-60.

[11] Moersid, Ananda Feria. (2013). Re-Invention of Batik and Identity of Indonesia in Global Market Arena. Ilmiah Widya Journal, Vol. 1, No. 2, pp 121-128.

[12] Mashdurohatun, Anis \& Setyawati. (2017). Ideal Construction of Legal Protection on Batik Based on Pancasila Justice Values. International Journal of Business, Economics and Law, Vol. 13, Issue 4, pp 189-198

[13] Ningsih, Dyana Novita. (2015). Indonesian Batik Export to the United State in 2010 - 2014. Jom FISIP Journal, Vol. 2 No. 2, pp 1-15.

[14] Nila Krisnawati, Nila, Loina K Perangin-angin, Munawaroh Zainal, Imelda Suardi. (2016). Brand equity analysis and its impact on the loyal customer of local batik to develop its competitiveness (An empirical study of batik Banten in south tangerang). Journal of Administrative and Business Studies, Vol. 2(4): 189-207

[15] Parmono, Kartini. (2013). Value of Local Wisdom in Tradisional Kawung. Filsafat Journal, Vol. 23, No. 2, pp 134146

[16] Rosyidah, Elok. (2016). Rebranding values of Jember Batik as Education Efforts and realizing Segmentation of Jember Local Product. National Seminar Proceedings, Global Dinamics: Rebranding Advantanges Competitive Based on Local wisdom, Pascasarjana UNEJ Building, pp 12-20.

[17] Sardjono, Agus, Brian Amy Prastyo, Derezka Gunti Larasati. (2015). Development of Collective Trademark For Batik 
Industry in Kampung Batik Laweyan (Laweyan Batik's Village), Solo. Indonesian Law Review Journal. Vol. No. 1, pp 33-50.

[18] Sardjono, Agus, Brian Amy Prastyo, \& Desrezka Gunti Larasati. (2013). The Implementation of Protection Trademark for Entrepreneurs Batik in Pekalongan, Solo, and Yogyakarta. Hukum dan Pembangunan Journal, 43, No. 4, pp 470-491.

[19] Steelyana, Evi. (2012). Batik, a Beautiful Cultural Heritage That Preserve Culture and Support Economic Development in Indonesia. Binus Business Review, Vol. 3, No. 1, pp 116130.

[20] Saddhono, Kundharu, Sahid Teguh Widodo, Muhammad Taufiq Al-Makmun, \& Masakatsu Tozu. (2014). The Study of Philosophical Meaning of Batik and Kimono Motifs to Foster Collaborative Creative Industry. Asian Social Science; Vol. 10, No. 9, p 52-61.
[21] Suryana. (2013). Enterpreneurship: Tips and Process for Sucess. Jakarta: Salemba Empat.

[22] Syarif Hidayat, Agi. (2015). Optimization export of Batik Cirebon, After the Implementation of Asean Economic Communities (AEC) in 2015. JP Journal \& Proceeding, Vol. 15, No. 1, hh 1-12.

[23] Ulum, Ihyaul. (2009). Batik and Its Contribution on National Economy. Bestari Journal, No. 42, XXII, pp 21-32.

[24] Widihastuti, Setiati, \& Eny Kusdarini. (2013). Intellectual Property Rights of Producer Batik, Case Study in Wukirsari Imogiri Bantul. Jurnal Penelitian Humaniora, Vol. 18, No. 2, pp 145-155

[25] Zahidi, M. Syapin. (2017). Batik As Indonesian Public Diplomacy in Asean Economic Community (AEC). International Journal of International Relations, Media and Mass Communication Studies. Vol.3, No.2, pp 1-9 
